\title{
ROZHOVORY
}

\section{Vzpomínka na Milana Mráze}

\section{Nad odkazem Milana Mráze}

Milan Mráz, jenž nás v loňském prosinci nečekaně opustil, byl nejen vynikající překladatel a badatel na poli filologickém a filosofickém, ale také výkonný ředitel, autor řady institucionálních koncepcí v rámci Filosofického ústavu, a v neposlední řadě oblíbený šéf relativně početných zaměstnanců ústavu. Pro velkou většinu z nich zůstával jakýmsi archetypálním ředitelem i po svém odchodu $\mathrm{z}$ této funkce a řada $\mathrm{z}$ nich se na něj stále obracela s žádostí o radu či řešení, jako kdyby ředitelem zůstal. Rozhodl jsem se tedy požádat o rozhovor dva Mrázovy nástupce, jeho dávného osobního prítele Viléma Herolda, jenž byl ochoten zprostředkovat čtenářům Mrázovu osobnost, a současného ředitele Pavla Barana, jenž vzhledem ke generační i časové césuře již pohlíží na Mrázovu éru s větším odstupem a může nabídnout širší zhodnocení jeho působení v ne-badatelské roli. 